\title{
Measurement of Green House Gases in the Environment of a Petroleum Refining and Petrochemical Company
}

\author{
AGAJA S. A. \\ Industrial Safety and Environmental Technology Petroleum Training Institute Effurun
}

\begin{abstract}
This work measures some green house gases in the environment of a Petroleum Refinery and petrochemical company. The study was accomplished by measuring the concentration of Carbon IV Oxide $\left(\mathrm{CO}_{2}\right)$ sulphur IV Oxide $\left(\mathrm{SO}_{2}\right)$, Nitrogen IV oxide $\left(\mathrm{NO}_{2}\right)$, and Methane $\left(\mathrm{CH}_{4}\right)$ which could cause adverse effect on the environment when they are emitted continuously. The measurement was carried out suing a calibrated insitu gas monitor known as Aeroqual digital Monitor and a sensor for each of the parameters. The analysis was carried out for a period of seven months (January-July, 2012) and the results obtained showed that mean concentration for $\mathrm{CO}_{2}$ ranged from 1235.5 to 1388.5 (ppm), while that of $\mathrm{SO}_{2}$ ranged from (0.17 to 0.19) (ppm) and $\mathrm{CH}_{4}$ from (0.07 to 0.09 (ppm). The concentration of $\mathrm{NO}_{2}$ is below the detection limit of the instrument. Also, the ambient temperature, relative humidity, wind speed and wind direction were measured with appropriate instruments. The $\mathrm{CO}_{2}$ levels were higher than the Federal Ministry of Environment and Department of Petroleum Resources (FMENV/DPR) standard. The ways to mitigate their effects on humans and environment are suggested.
\end{abstract}

Keywords: Petroleum Refinery, GHG, FMENV/DPR.

\section{Introduction}

Green House Gases (GHG), are gases in the atmosphere that absorb and emit radiation within the thermal infrared region. This process is the fundamental cause of green house effect. The dominant green house gases are water vapour, carbon iv oxide and methane others may be due to anthropogenic effects. The major sources of GHG into the atmosphere are: gas flaring, deforestation fossil fuel, industrial emission, farming practices and land use (Karl 2009).

Proper identification and quantification of GHG is Important to determine how the global Climate in changing, what drives these changes and the potential consequences is on humans and the environment (Berman 2012). Industrial process and human activities has altered the natural balance of green house gases and aerosols in the atmosphere and has consequently altered the climatic situation.

In Nigeria and some other crude oil producing countries gas flaring, oil spillage continues to pose several environmental challenges and negative impact on human health. Air pollution is likely to remain a major problem in Niger delta . Other Sources of air pollution such as automobiles diesel trucks and electricity generator contributes to elevated green house gases in the atmosphere. The aim of this study is to identify and quantify the green house gases around a Petroleum Refinery and Petrochemical Plant and to find out if the values obtained met the recommended standards by FMENV/DPR.

\section{Materials And Method}

The Aeroqual series 200 gas monitor with relevant sensors was used to identify and measure the concentration of $\mathrm{CO}_{2}, \mathrm{SO}_{2}, \mathrm{NO}_{2}$ and Methane in the air at a location some metres away from the Refinery and petrochemical plant. The gas monitor was earlier calibrated before it was used for measurement in the field. The probes of the gases of interest to be measured were fitted into the head of the gas monitor. Sampling duration lasted as specified by the meter for it to be on and the readings automatically displayed, this depends on the atmospheric conditions such as cloud and temperature at the time of taken measurement.

The ambient temperature, relative humidity, wind speed and wind direction were measured with the sky master instrument this is a pocket weather monitor. The geographical co-ordinate of the location was determined using Germain GPS Navigation device. This was used to measure the latitude and longitude of the location. 
Table 1: Instrument used.

\begin{tabular}{|l|l|l|}
\hline S/N & PARAMETERS & TYPES OF INSTRUMENT AND MODEL \\
\hline & Carbon iv oxide $\left(\mathrm{CO}_{2}\right)$ & Aeroqual Digital Monitor (200) \\
& $\begin{array}{l}\text { Nitrogen iv oxide }\left(\mathrm{NO}_{4}\right) \\
\text { Sulphur iv oxide }\left(\mathrm{SO}_{4}\right) \\
\text { Methane }\left(\mathrm{CH}_{4}\right) \text { or }(\mathrm{VOC})\end{array}$ & \\
\hline & $\begin{array}{l}\text { Ambient temperature } \\
\text { Relative humidity } \\
\text { Wind speed/wind direction }\end{array}$ & Sky Master Instrument \\
\hline & Latitude and Longitude & GPS (Global Positioning System) \\
\hline
\end{tabular}

III. Results And Discussions

Table 2: Monthly Concentration of Green House Gases.

\begin{tabular}{|c|c|c|c|c|c|c|c|c|}
\hline \multirow{2}{*}{$\begin{array}{l}\text { PARAMETER } \\
\text { S }\end{array}$} & \multirow{2}{*}{$\begin{array}{l}\text { FMENV/ } \\
\text { DPR } \\
\text { LIMIT }\end{array}$} & \multicolumn{7}{|c|}{ MONTHLY MEASUREMENT } \\
\hline & & JANUARY & FEBRUARY & MARCH & APRIL & MAY & JUNE & JULY \\
\hline $\mathrm{CO}_{2}\left(\mathrm{mg} / \mathrm{m}^{3}\right)$ & 900 & 1320.90 & $1257 / 91$ & 942.15 & 1360.49 & 148.26 & 1510.46 & 1307 \\
\hline $\mathrm{NO}_{2}\left(\mathrm{mg} / \mathrm{m}^{3}\right)$ & 0.05 & $\mathrm{BDL}$ & BDL & $\mathrm{BDL}$ & $\mathrm{BDL}$ & BDL & BDL & BDL \\
\hline $\mathrm{SO}_{2}\left(\mathrm{mg} / \mathrm{m}^{3}\right)$ & 0.26 & 0.12 & 0.18 & 0.21 & 0.16 & 0.21 & 0.19 & 0.16 \\
\hline $\mathrm{CH}_{4}\left(\mathrm{mg} / \mathrm{m}^{3}\right)$ & 0.16 & 0.09 & 0.12 & 0.10 & 0.08 & 0.06 & 0.04 & 0.05 \\
\hline $\begin{array}{l}\text { wind speed } \\
(\mathrm{m} / \mathrm{s})\end{array}$ & N/A & 2 & 2 & 3 & 3 & 5 & 4 & 4 \\
\hline $\begin{array}{l}\text { WIND } \\
\text { DIRECTION }\end{array}$ & N/A & $\mathrm{S} / \mathrm{W}$ & $\mathrm{S} / \mathrm{W}$ & $\mathrm{S} / \mathrm{W}$ & S/W & $\mathrm{S} / \mathrm{W}$ & $\mathrm{S} / \mathrm{W}$ & $\mathrm{S} / \mathrm{W}$ \\
\hline $\begin{array}{l}\text { AMBIENT }\left({ }^{\circ} \mathrm{C}\right) \\
\text { TEMPERATU } \\
\text { RE }\end{array}$ & N/A & 31.1 & 31.8 & 37.6 & 29.4 & 29.5 & 29.9 & 29.5 \\
\hline $\begin{array}{l}\text { RELATIVE } \\
\text { HUMIDITY }\end{array}$ & N/A & 39 & 33.0 & 38.2 & 29.8 & 32.4 & 30.6 & 30.6 \\
\hline COORDINATE & N/A & $\begin{array}{l}\mathrm{N} \\
05.56655^{\circ} \\
\mathrm{E} 005.72412\end{array}$ & $\begin{array}{l}\mathrm{N} 05.56655^{\circ} \\
\mathrm{E} 005.72412\end{array}$ & $\begin{array}{l}\mathrm{N} \\
05.56655^{\circ} \\
\mathrm{E} 005.72412\end{array}$ & $\begin{array}{l}\mathrm{N} \\
05.56655^{\circ} \\
\text { E005.72412 }\end{array}$ & $\begin{array}{l}\mathrm{N} \\
05.56655^{\circ} \\
\mathrm{E} 005.72412\end{array}$ & $\begin{array}{l}\mathrm{N} \\
05.56655^{\circ} \\
\mathrm{E} 005.72412\end{array}$ & $\begin{array}{l}\mathrm{N} \\
05.566 \\
55^{\circ} \\
\text { E005.7 } \\
2412 \\
\end{array}$ \\
\hline
\end{tabular}

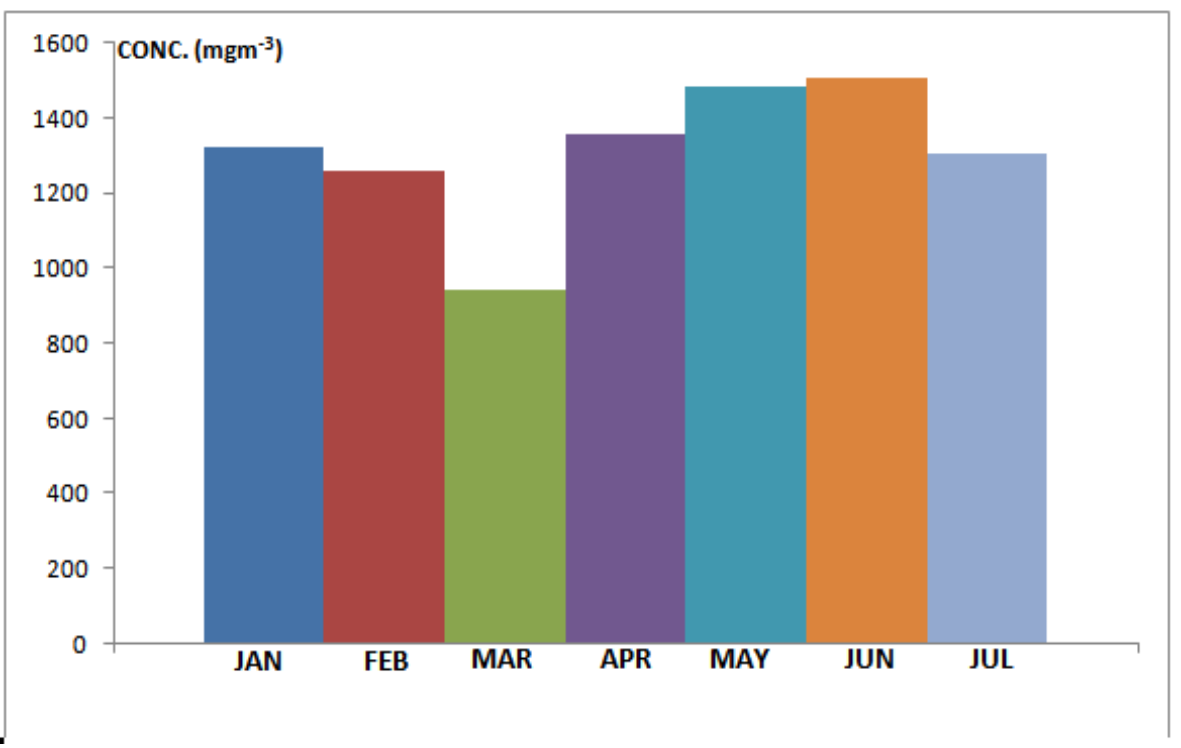

Fig. 1: Concentration of $\mathrm{CO}_{2}$ in air. 


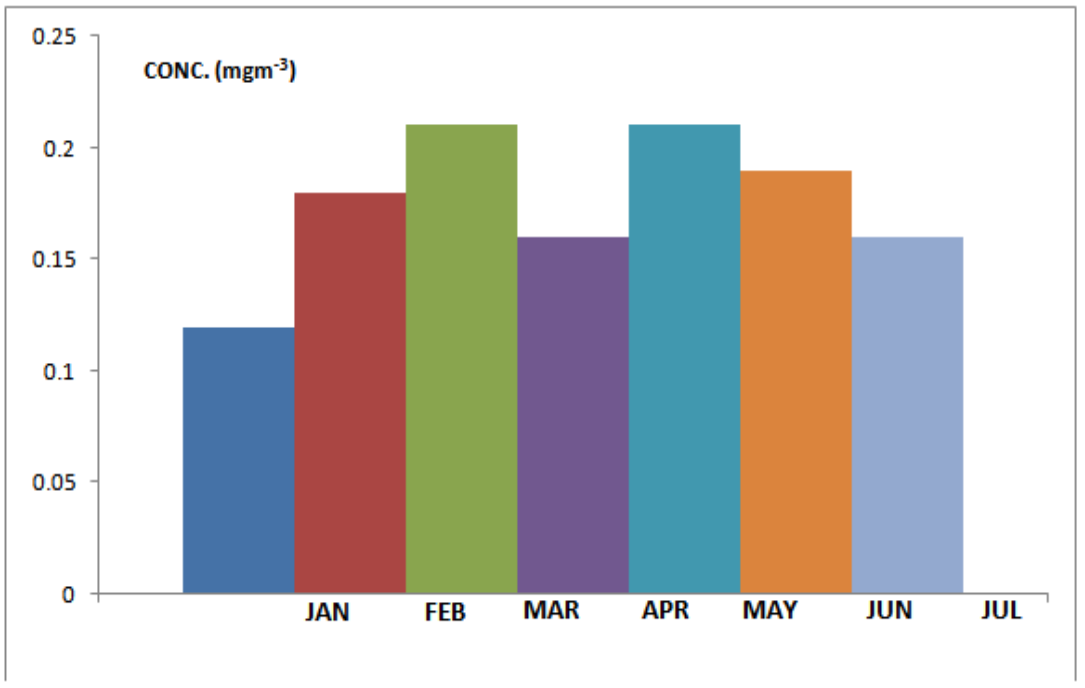

Fig. 2: Variation in concentration of $\mathrm{SO}_{2}$ in air.

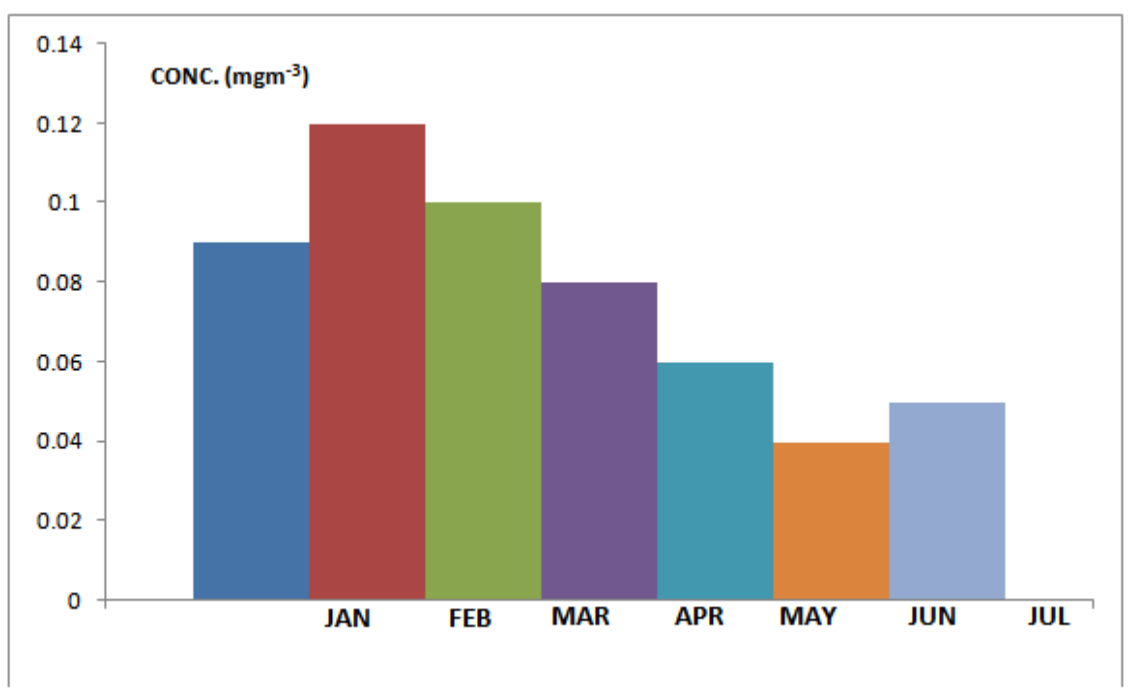

Fig. 3: Variation in concentration of $\mathrm{CH}_{4}$ in air.

The summary of the GHG Concentration Measured was shown in Table 2.

The carbon iv oxide concentration ranged between (942-1511) $\mathrm{mgm}^{-3}$ with a mean value of $1312 \pm 76$. However, these values were above the Federal Ministry of Environment and Department of Petroleum Resources Recommended Standard value of $900 \mathrm{mgm}^{-3}$ for Carbon iv oxide in air.

Nitrous iv oxide Concentration were below detection limit in the air throughout the duration of the study. Sulphur iv oxide concentration ranged between $(0.12-0.21) \mathrm{mgm}^{-3}$ in air with mean value of 0.18 $0.01 \mathrm{mgm}^{-3}$ the values were below the FMEWV/DPR recommended standard value of $0.26 \mathrm{mgm}^{-3}$.

The methane concentration in air ranged from $(0.04-0.12) \mathrm{mgm}^{-3}$ with mean value of $0.08 \pm 0.01 \mathrm{mgm}^{-3}$ in air. These values measured were below the FMENV/DPR standard value of $0.16 \mathrm{mgm}^{-3}$.

The concentration of the green house gases in air were correlated with the ambient temperature. The Correlation coefficient $\mathrm{r}$, between $\mathrm{CO}_{2}$ and ambient temperature $\mathrm{r}=-0.9$ this shows a strong negative correlation implying that at higher ambient temperature the concentration of carbon iv oxide in air decreases and vice versa for $\mathrm{SO}_{2} \mathrm{r}=0.3$ this is a low positive correlation in order words as the ambient temperature increase, the concentration of $\mathrm{SO}_{2}$ also rises very slowly.

For $\mathrm{CH}_{4} \mathrm{r}=0.7$. This show a high positive correlation implies the concentration of methane in air will increase at appreciable rate with rise in ambient temperature.

\section{Conclusion}

The Green House Gases $\left(\mathrm{CO}_{2}, \mathrm{NO}_{2}, \mathrm{SO}_{2}\right.$ and $\left.\mathrm{CH}_{4}\right)$ Concentration in air within the environment of a petroleum Refining and Petrochemical plant have been measured. Measurement was carried out for seven months (January to July) mean concentrations for $\mathrm{CO}_{2}, \mathrm{SO}_{2}$ and $\mathrm{CH}_{4}$ are: $1312 \pm 76 \mathrm{mgm}-3 \quad 0.18 \pm 0.01 \mathrm{mgm}-3$ 
$0.08 \pm 0.01 \mathrm{mgm}-3$ respectively. The concentration of $\mathrm{NO}_{2}$ in air was below detection limit. The concentration of $\mathrm{CO}_{2}$ in air was above the recommended threshold value of $900 \mathrm{mgm}_{-3}$ of FMEWV/DPR. The elevated concentration of $\mathrm{CO}_{2}$ in air is mainly due to industrial activities on going like oil and gas processing and gaseous emission by automobiles.

\section{Recommendations}

- Vehicular emission assessment must be carried out on all vehicles to reduce emission of carbon iv oxide to the air.

- Indiscriminate bush burning practices, burning of refuse and uncontrolled felling of trees should be discouraged.

- It is important to develop a standard regulation that will control the emission of green house gases, so as to boost public health and tackle global warming.

- Gas flare-out policy of the government must be ensured quickly.

\section{References}

[1] Berman, E. S. F, Fladeland, M, Liem, J, Icolyer, R and Gupta, M (2012): Green house gas analyzer for measurements of CO $\mathrm{CH}_{4}$ and $\mathrm{H}_{2} \mathrm{O}$ vapour abroad an unmanned aerial vehicle; Sens. Actuator B:Chem. http://dx.doi.org/

[2] 10.1016/J.snb.2012.04.036 \{Article in Press\}

[3] Carbon Trust March (2009): Global Carbon Mechanisms: Emerging Lessons and Implications (CTC 748)

[4] Federal Environmental Protection Agency, (1991): Guidelines and Standards for Environmental Pollution Control in Nigeria.

[5] Karl, T. R. Trenberth, K. E (2003): Modern Global Climate Change, Science, 302 (5651): 179-23.

[6] Team C. W, Pachamri, R. K. and Reisinger, A (2007): Climate change 2007 Synthesis report, contribution of working groups I II and III to the 4th Assessment report of the intergovernmental pared on climate change IPCE, Geneva, Switzerland 104. 